\title{
Tissue Preservation with Natural Fixatives: An Immunohistochemical Evaluation
}

\author{
${ }^{1}$ Barnali Majumdar, ${ }^{2}$ Roopa S Rao, ${ }^{3}$ Shankargouda Patil
}

\begin{abstract}
Background: The search for formalin substitute has been enduring from the time it was proven as a carcinogen. The natural sweetener, jaggery, as a tissue fixative has already been established and its compatibility with special stains demonstrated in our previous study. Hence, in the present study, the efficacy of jaggery, along with honey, was further evaluated using immunohistochemical procedures.
\end{abstract}

Materials and methods: A cross-sectional study with 30 samples of commercially available fresh goat oral mucosa, fixed with $10 \%$ buffered formalin (positive control), $20 \%$ honey, and $30 \%$ jaggery solution was conducted. After 24 hours of fixation, tissue sections were subjected to immunohistochemical stains pan-cytokeratin and desmin. Following which blinded evaluation was done by two examiners. Statistical analysis was accomplished using Kruskal-Wallis analysis of variance, Mann-Whitney $U$ test, chi-square test, and Kappa statistics.

Results: The pan-cytokeratin staining intensity of jaggeryfixed tissues $(2.67 \pm 0.488)$ was observed to be more intense than honey $(1.60 \pm 0.507, p<0.001)$ and formalin $(2.13 \pm 0.352$, $p=0.003)$-fixed tissues. Jaggery $(2.33 \pm 0.617)$ and formalin $(2.40 \pm 0.632)$ showed comparable results with respect to desmin.

Conclusion: Based on the findings, the fixative properties of jaggery surpassed honey and was found to be on par with formalin.

Keywords: Formalin-substitute, Honey, Hydroxymethylfurfural, Immunohistochemistry, Jaggery.

How to cite this article: Majumdar B, Rao RS, Patil S. Tissue Preservation with Natural Fixatives: An Immunohistochemical Evaluation. World J Dent 2016;7(2):87-91.

Source of support: Nil

Conflict of interest: None

\section{INTRODUCTION}

A good histopathological technique aims to produce microscopic preparations of the tissues that are identical

${ }^{1}$ Postgraduate Student, ${ }^{2}$ Professor and Head, ${ }^{3}$ Associate Professor

${ }^{1-3}$ Department of Oral Pathology and Microbiology, Faculty of Dental Sciences, MS Ramaiah University of Applied Sciences Bengaluru, Karnataka, India

Corresponding Author: Barnali Majumdar, Postgraduate Student, Department of Oral Pathology and Microbiology, Faculty of Dental Sciences, MS Ramaiah University of Applied Sciences Bengaluru, Karnataka, India, Phone: +918095376400, e-mail: barnali_bkm@yahoo.co.in to their original configuration. Preservation of the tissues can be attained with a wide variety of fixatives, by which the constituents of the cells and tissues are fixed in their physical and chemical life-like state. However, in practical application, an ideal fixative is challenging to formulate and each fixative has its own merits and shortcomings. ${ }^{1}$

In diagnostic pathology, $10 \%$ neutral buffered formalin (NBF) has been given an extra edge as a fixative, but is equally hazardous to the health of living beings, as discussed extensively in our previous study. Briefly, it is a proven group 1 carcinogen, as stated by the International Agency for Research on Cancer (IARC) and does not assure a complete antigen, deoxyribonucleic acid (DNA) and ribonucleic acid (RNA) recovery, essential to many modern investigations of molecular biology., 2,3

Concerning the last disadvantage stated, the present study evaluated the compatibility of natural fixatives in relation to retrieval of the tissue antigens. Immunohistochemical (IHC) technique aids in identifying the cellular antigens by means of specific antigen-antibody interactions, which can be visualized through light microscopy. ${ }^{1,4}$ The fixative potential of the natural sweeteners, jaggery and honey, along with their compatibility with the routine and special staining procedures, has been previously demonstrated. ${ }^{5,6}$ In the present study, further evaluation of the compatibility and efficacy of the natural tissue fixatives with the IHC procedures was accomplished.

\section{MATERIALS AND METHODS}

\section{Sample Size and Procedure}

Thirty samples of commercially available fresh goat oral mucosa was procured and sectioned into three bits of equal size $(0.5 \times 0.5 \times 0.5 \mathrm{~cm})$. The sectioned tissues were immediately placed in three different containers with fresh solutions of $10 \% \mathrm{NBF}$ (positive control), $20 \%$ honey, and $30 \%$ jaggery solutions. Commercially available honey (Dabur India Ltd.) and jaggery (local sugarcane source, Bengaluru, India) were used to prepare the solutions. Dilutions were prepared with distilled water. Prior to fixation, the $\mathrm{pH}$ of the solutions was noted to be 5.5 for $30 \%$ jaggery, 4.5 for $20 \%$ honey, and 7.2 for $10 \%$ NBF. After 24 hours of fixation, tissues were subjected to routine tissue processing wherein the duration of wax impregnation 
was increased (2.5 hours for each change of wax), following which $4 \mu \mathrm{m}$ sections were obtained and were subjected to hematoxylin and eosin stain for assessing the tissue histomorphology, prior to subjecting the samples (15 sections each) to IHC markers, pan-cytokeratin and desmin.

\section{Immunohistochemical Staining}

For IHC staining, 4- $\mu$ m-thick sections were made and mounted on silane-coated glass slides. The tissue sections were de-paraffinized and rehydrated in graded ethanol solutions. Antigen was retrieved with Trisethylenediaminetetraacetic acid buffer solution $(\mathrm{pH}$ 8.0) via microwave technique for 25 minutes, followed by a peroxidase block applied for 10 to 15 minutes and incubated with the primary antibodies pan-cytokeratin and desmin (Biogenex, India) for an hour. Then the super enhancer and polymer horseradish peroxidase (polymeric peroxidase-conjugated anti-mouse/rat/ rabbit immunoglobulin G secondary antibody) were applied and the reactions were developed with DAB (3,3'-diaminobenzidine) chromogen. Finally, the sections were counterstained with Harris hematoxylin. Positive control employed for pan-cytokeratin was breast carcinoma and for desmin was cardiac muscle tissue. Only the cytoplasmic staining was considered as positive. Subsequently, the slides were coded and were subjected to blinded evaluation using the optical microscope under $10 \times$ magnification. The staining intensity was graded as; 0 - negative, 1 - weakly positive, 2 - moderately positive, and 3 - strongly positive. ${ }^{7}$

\section{Statistical Analysis}

The results were tabulated and subjected to statistical analysis using Kruskal-Wallis analysis of variance, MannWhitney U test, chi-square test, and Kappa statistics via Statistical Package for the Social Sciences (SPSS) 10.5 software. A p-value of $<0.001$ was considered significant.

\section{RESULTS}

The pictomicrographic demonstrations of the IHC stains are represented in Figure 1.

Pan-cytokeratin marker: The staining of jaggery-fixed tissues (JFT) $(2.67 \pm 0.488)$ was observed to be more intense than honey-fixed tissues (HFTs) $(1.60 \pm 0.507)$ and formalin-fixed tissues (FFTs) $(2.13 \pm 0.352)$. This difference in intensity was statistically significant between honey and jaggery $(\mathrm{p}<0.001)$.

Desmin marker: The JFT $(2.33 \pm 0.617)$ and FFT $(2.40 \pm 0.632)$ showed comparable results with no statistically significant difference in the staining intensity $(\mathrm{p}=0.745)$. However, the intensity of HFT $(0.73 \pm 0.594)$ was significantly inferior to that of JFT and FFT $(p<0.001)$.

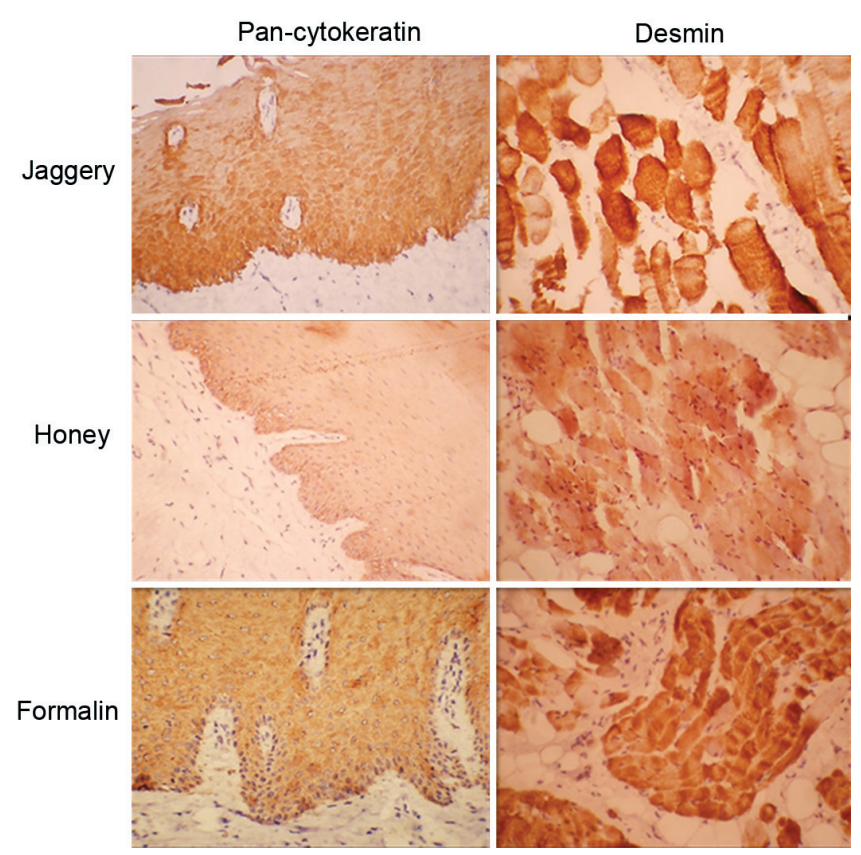

Fig. 1: Intensity of the immunohistochemical stains

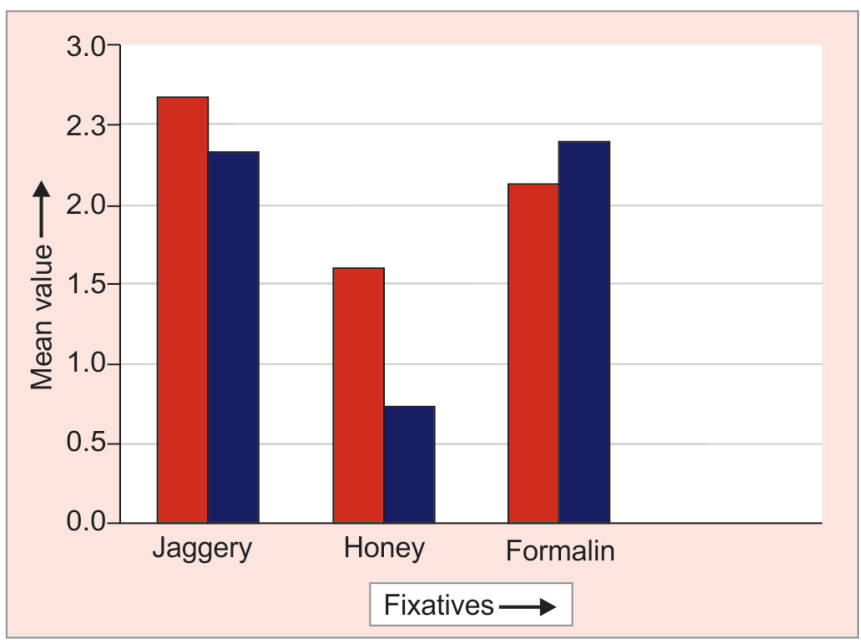

Graph 1: Comparison of mean value of the immunohistochemical staining among the three fixatives (red: pan cytokeratin, blue: desmin)

The kappa statistics showed moderate to substantial agreement among the examiners. The comparison of the IHC staining procedures among the three fixatives is depicted in Graph 1.

\section{DISCUSSION}

Tissue fixation is the prime step in histopathological diagnosis. The outcomes of the various IHC procedures are fairly liable to the type of fixative treatment. The fixative modifies the physicochemical state of the tissue, thereby altering the reactivity of the cellular constitutions toward the stains. ${ }^{8}$ Thus, the present study investigated the efficacy of the natural fixatives in preservation of the epithelial and connective tissue antigenic components using the IHC markers. 
The fixative $10 \%$ NBF falls under the category of aldehyde group. The commercially available unbuffered formalin has a $\mathrm{pH}$ of 4.0 (approx.). To prepare 10\% NBF with the above solution, sodium phosphate mono- and dibasic dehydrate is added. It raises the $\mathrm{pH}$ to 7.2 to 7.4 range. Also, it prevents the formation of formalin pigments. ${ }^{9}$

As mentioned previously, one of the drawbacks of $10 \%$ $\mathrm{NBF}$ is incomplete antigen, DNA and RNA recovery. This can be explained by the (1) mechanism of fixation and (2) $\mathrm{pH}$ of the formalin. (1) The initial reversible cross-links are formed within 24 to 48 hours, whereas more number of stable, irreversible, covalent bonds are formed in about 30 days. Hence, technically, in fresh FFTs the antigen retrieval is more productive, rather than from the archival tissues. $^{9}$ (2) With respect to $\mathrm{pH}$ of formalin and antigen retrieval, it is postulated that most of the tissue fixation occurs in a $\mathrm{pH}$ range of 4.0 to $5.5 \mathrm{pH}$. Further increase in $\mathrm{pH}$ above 5.5 does not aid in stabilization of the tissue. Correspondingly, with increase in $\mathrm{pH}$, more number of reactive groups are bound by formaldehyde and as a result yields in reduced antigenicity of the tissues. ${ }^{8}$

Honey is known for its remarkable medicinal properties and as the first natural sweetener to the people of various cultures around the world. ${ }^{10}$ It is a golden yellow-amber-colored viscous fluid made by honey bees from floral sources. ${ }^{10,11}$ Jaggery is a natural sweetener obtained from sugarcane juice or the sap collected from some palm trees. It is stated to have antitoxic and anticarcinogenic properties. Its structure is far complex than that of the common sugar, as it is made up of longer chains of sucrose. ${ }^{12,13}$
The previous study by Patil et al ${ }^{5}$ piloted for the first time in literature the use of jaggery as a successful tissue fixative. Later in 2015, they verified that it can be used for long-term tissue preservation as well. ${ }^{6}$ The present study further investigated the compatibility of JFTs with IHC procedures. The composition and function of each component of jaggery and floral honey are depicted in Tables 1 and 2 respectively. ${ }^{12-14}$

The mechanism of fixation by jaggery and honey is proposed in Flow Chart 1.,15-17 The preliminary step involves the formation of hydroxymethylfurfural (HMF). It is a furanic compound, formed as an intermediate product in the Maillard's reaction. The reaction naturally occurs in substances containing reducing sugars and proteins, like honey, milk, etc. which is further accelerated in presence of an acidic medium or heat treatment during manufacturing. ${ }^{15,16}$ The second step in the fixation process involves cross-linking of the proteins present in the

Table 1: Composition and properties of jaggery

\begin{tabular}{|c|c|c|c|}
\hline Sl. no. & Constituent & Percentage & Function \\
\hline \multirow[t]{3}{*}{1} & Reducing sugars & & \multirow{3}{*}{$\begin{array}{l}\text { High nutritional } \\
\text { value }\end{array}$} \\
\hline & - Sucrose & $65-85$ & \\
\hline & - Fructose and Glucose & $10-15$ & \\
\hline 2 & Proteins & 0.4 & \multirow{5}{*}{$\begin{array}{l}\text { Antitoxic and } \\
\text { anticarcinogenic } \\
\text { properties }\end{array}$} \\
\hline 3 & Fat & 0.1 & \\
\hline \multirow[t]{2}{*}{4} & Minerals & & \\
\hline & $\begin{array}{l}\text { calcium, phosphorus, } \\
\text { iron, magnesium, } \\
\text { potassium, sodium, } \\
\text { manganese, zinc, } \\
\text { copper, chloride }\end{array}$ & $0.6-1.0$ & \\
\hline 5 & Moisture & $3-10$ & \\
\hline
\end{tabular}

Table 2: Composition and properties of floral honey

\begin{tabular}{|c|c|c|c|}
\hline SI. no. & Constituent & Percentage & Function \\
\hline \multirow[t]{2}{*}{1} & Reducing sugars & & \\
\hline & $\begin{array}{l}\text { - Fructose } \\
\text { - Glucose } \\
\text { - Sucrose } \\
\text { - Maltose } \\
\text { - Higher sugars }\end{array}$ & $\begin{array}{l}27.25-44.26 \\
22.03-40.75 \\
0.25-7.57 \\
2.74-15.98 \\
0.13-8.49\end{array}$ & Main constituents that provide sweetness \\
\hline 2 & Proteins and amino acids & $0.04-0.1$ & Lowers surface tension \\
\hline 3 & $\begin{array}{l}\text { Acids } \\
\text { Gluconic acid (main) } \\
\text { Other - ascorbic, formic, acetic, etc. }\end{array}$ & $<0.5$ & $\begin{array}{l}\text { Excellent stability of honey against } \\
\text { microorganisms }\end{array}$ \\
\hline 4 & $\begin{array}{l}\text { Enzymes } \\
\text { - Invertase } \\
\text { - Diastase } \\
\text { - Glucose oxidase }\end{array}$ & & $\begin{array}{l}\text { - Aids in maintenance of sucrose equilibrium } \\
\text { - Function is not clear } \\
\text { - Formation gluconic acid, hydrogen peroxide } \\
\text { (antimicrobial activity) }\end{array}$ \\
\hline 5 & $\begin{array}{l}\text { Minerals } \\
\text { potassium, sodium, chlorine, calcium, magnesium, } \\
\text { magnesium, iron, manganese, copper, magnesium, sulfur } \\
\text { and silicon }\left(\mathrm{as} \mathrm{SiO}_{2}\right) \text {, chromium, lithium, nickel, lead, tin, } \\
\text { zinc, osmium, beryllium, vanadium, zirconium, silver, barium, } \\
\text { gallium, bismuth, gold, germanium, and strontium }\end{array}$ & $0.02-1.03$ & Maintenance of $\mathrm{pH}$ \\
\hline 6 & Moisture & $13.4-22.9$ & Influences quality and granulation of honey \\
\hline
\end{tabular}


Flow Chart 1: The known mechanism of formaldehyde and the proposed mechanism of action of the natural fixatives

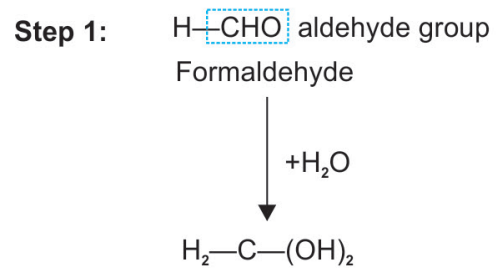

Step 2: Methylene glycol

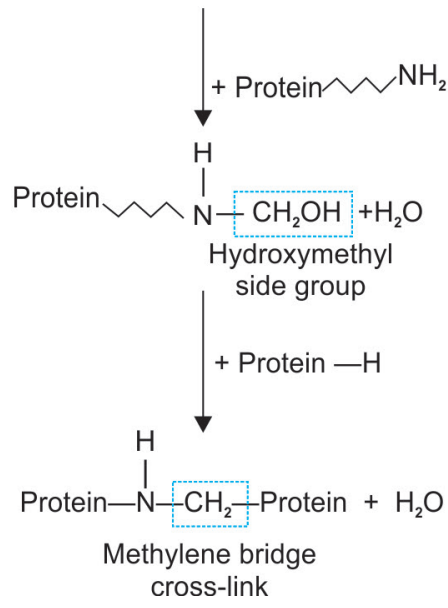

tissues by HMF through the di-Schiff base reaction. ${ }^{17}$ Apart from the proteins, nucleic acid fixation may also take place by reaction of HMF with the free amino groups of the nucleotides. Likewise, amino group containing lipids and carbohydrates, such as ethanolamine and glycoproteins, may react with HMF and form crosslinks.

A limited number of studies have been conducted on honey as a tissue fixative. Rahma Al-Maaini and Philip Bryant ${ }^{18,19}$ and Özkan et $\mathrm{al}^{20}$ evaluated the connective tissue staining quality of the HFT. Both of the studies showed that HFT had minor histomorphological differences and did not affect the diagnosis. Guntur and Bryant $^{21}$, Özkan et $\mathrm{al}^{20}$ and Sabarinath et $\mathrm{al}^{22}$ further evaluated IHC staining properties of HFT, which was found to be comparable to that of FFT. In the present study, epithelial marker pan-cytokeratin showed comparable results to that of FFT; however, staining with desmin was found to be inferior to both JFT and FFT.

To best of our knowledge, this is the first study that has evaluated the potential of JFT for IHC staining. The results showed superior staining of the epithelial and muscle markers in the JFT when compared with the HFT. Further, the staining quality was slightly higher for the epithelial marker when compared to that of FFT.

One of the significant findings of the present study was the superior staining quality of the epithelial component, that is, cytokeratins in JFT when compared with formalin. Hence, 30\% jaggery solution can be particularly used in suspected cases of epithelial pathology. Likewise,
Step 1: Reducing sugars + Amino acids
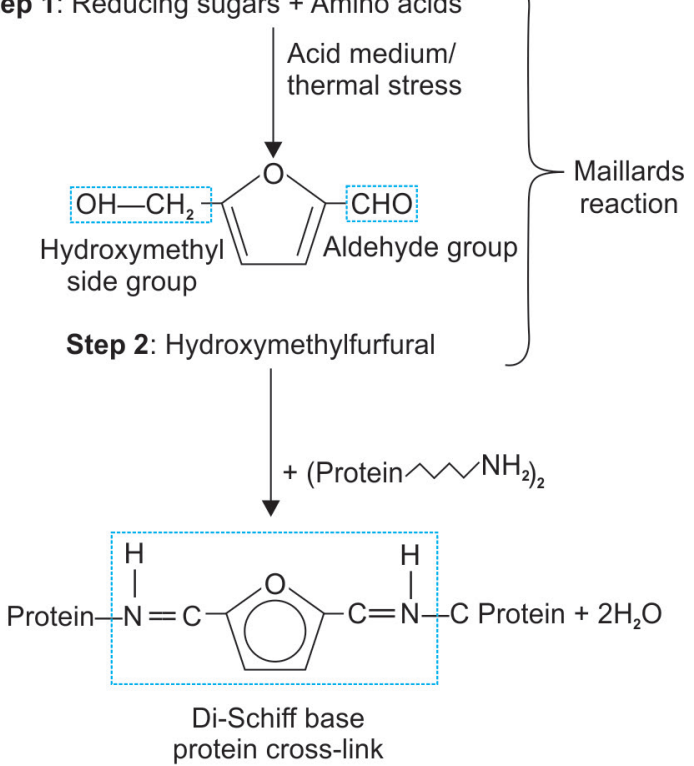

concerning desmin staining, the results were statistically insignificant between JFT and FFT. These findings can possibly be explained based on the extent of antigen retrieval. The antigen retrieval method employed in the present study was heat mediated in an alkaline medium. It is postulated that heat-mediated antigen retrieval removes the weaker Schiff bases (main mechanism of natural fixative) but does not affect the methylene bridges (main mechanism of formalin fixation). ${ }^{1}$

Further, the superior staining quality of the JFT to that of HFT can possibly be explained based on the amount of production of HMF. The composition of jaggery shows that it has a higher protein content $(0.4 \%$ average) and an almost equal amount of reducing sugars (20\% average) when compared to honey, hence more substrate is available for the Maillards reaction in the jaggery solution.

One of the drawbacks with the natural fixative solutions is that they undergo fermentation and crystallization owing to their high sugar content. Hence, they should be stored in a cool, dry place and diluted solutions should be freshly prepared as and when required.

\section{CONCLUSION}

To conclude, the present study offers an innovative proposal of using natural sweeteners, especially our traditional Indian sweetener jaggery, as a milestone in the quest for formalin substitute. The results are promising and invoke extensive research in the future. 


\section{REFERENCES}

1. Bancroft, JD.; Gamble, M. Theory and practice of histological techniques. 6th ed. Philadelphia, PA: Churchill Livingstone, Elsevier; 2008.

2. International Agency for Research on Cancer Monographs. Chemical agents and related occupations: a review of human carcinogens - formaldehyde. Vol. 100F. Switzerland: WHO Press; 2012. p. 401-435.

3. GillespieJW, Best CJ, Bichsel VE, Cole KA, GreenhutSF, Hewitt SM, Ahram M, Gathright YB, Merino MJ, Strausberg RL, et al. Evaluation of non-formalin tissue fixation for molecular profiling studies. Am J Pathol 2002 Feb;160(2):449-457.

4. Schacht V, Kern JS. Basics of immunohistochemistry. J Invest Dermatol 2015 Mar;135(3):e30.

5. Patil S, Premalatha BR, Rao RS, Ganavi BS. Revelation in the field of tissue preservation - a preliminary study on natural formalin substitutes. J Int Oral Health 2013 Feb;5(1): 31-38.

6. Patil S, Rao RS, Ganavi BS, Majumdar B. Natural sweeteners as fixatives in histopathology: a longitudinal study. J Nat Sci Biol Med 2015 Jan-Jun;6(1):67-70.

7. Domagala W, Lasota J, Bartkowiak J, Weber K, Osborn M. Vimentin is preferentially expressed in human breast carcinomas with low estrogen receptor and high Ki-67 growth fraction. Am J Pathol 1990 Jan;136(1):219-227.

8. Meyer, W.; Hornickel, I. Tissue fixation - the most underestimated methodical feature of immunohistochemistry. In: MndezVilas, A.; Daz, J., editors. Microscopy: science, technology, applications and education. Badajoz: Formatex Research Centre; 2010. p. 953-959.

9. Thavarajah R, Mudimbaimannar VK, Elizabeth J, Rao UK, Ranganathan K. Chemical and physical basics of routine formaldehyde fixation. J Oral Maxillofac Pathol 2012 Sep;16(3): 400-405.

10. Singh A, Hunasgi S, Koneru A, Vanishree M, Ramalu S, Manvikar V. Comparison of honey with ethanol as an oral cytological fixative: a pilot study. J Cytol 2015 Apr-Jun;32(2): 113-117.
11. Avwioro G, Bankole J, Iyiola S, Avwioro T, Akinola G. One of the properties of honey in wound healing is prevention of autolysis. Der Pharmacia Lettre 2010;2(3):321-325.

12. Nath A, Dutta D, Kumar P, Singh JP. Review on recent advances in value addition of jaggery based products. J Food Process Technol 2015 Jan-Mar;6(4):1-2.

13. Rao PVK, Das M, Das SK. Jaggery - a traditional Indian sweetener. Indian J Tradit Know 2007 Jan;6(1):95-102.

14. White, JW.; Doner, LW. Honey composition and properties: beekeeping in the United States. Agriculture Handbook No. 335; 1980. p. 82-91.

15. Ribeiro RDOR, Carneiro CDS, Mársico ET, Cunha FL, Conte Junior CA, Mano SB. Influence of the time/temperature binomial on the hydroxymethylfurfural content of floral honeys subjected to heat treatment. Ciência e Agrotecnologia 2012 Apr;36(2):204-209.

16. Bastos, DM.; Monaro, E.; Siguemoto, E.; Séfora, M. Maillard reaction products in processed food: pros and cons. In: Valdez B, editor. Food industrial processes - methods and equipment. Croatia: InTech Publishing; 2012.

17. Shapiro, HK. Use of pharmaceutical compounds in the treatment of symptoms of disorders related to neurological diseases and etiologically related symptomology [Internet]; 1992 [Filing date 1992 Feb 21; published 1992 Sep 3; cited 2015 Oct 7]. Available from: http://www.google.co.in/patents/ WO1992014456A1?cl=en

18. Al-Maaini R, Bryant P. The effectiveness of honey as a substitute for formalin in the histological fixation of tissue. J Histotechnol 2006 Aug;29(3):173-176.

19. Al-Maaini R, Bryant P. Honey as an alternative to formalin in the demonstration of connective tissue components. J Histotechnol 2008 Apr;31(2):67-72.

20. Özkan N, Şalva E, Çakalağaoğlu F, Tüzüner, B. Honey as a substitute for formalin?. Biotech Histochem 2012 Feb;87(2):148-153.

21. Gunter M, Bryant P. Immunocytochemical evaluation of ductal carcinoma in breast after preservation in honey. J Histotechnol 2009 Mar;32(2):54-59.

22. Sabarinath B, Sivapathasundharam B, Sathyakumar M. Fixative properties of honey in comparison with formalin. J Histotechnol 2014 Mar;37(1):21-25. 